\title{
OBSESIVNÍ CVIČENÍ JAKO ZÁVISLOST NEBO KOMPENZAČNÍ MECHANISMUS U PORUCH PŘÍJMU POTRAVY
}

\author{
Lenka Mynařiková
}

Abstrakt

Příspěvek z praxe představuje dvě kazuistiky klientek, které vyhledaly odbornou pomoc kvưli potížím s obsesivním cvičením, majícím negativní dopad na jejich osobní i pracovní život a zdravotní i psychický stav. V dnešní společnosti, ve které je kladen velký tlak na výkon a na fyzický vzhled, je pravidelné cvičení jako součást zdravého životního stylu žádoucí strategií zvyšování síly a vytrvalosti. Může být tedy snadné i nadměrné cvičení oceňovat a považovat za doklad fyzické a duševní síly. V předložených kazuistikách je patrné, že si obě ženy skutečný dopad svého chování uvědomily až po několika letech intenzivního každodenního cvičení trvajícího okolo tří až šesti hodin denně, kdy si svůj osobní i pracovní život musely organizovat kolem cvičebních jednotek namísto toho, aby cvičily pro zdraví nebo radost.

První kazuistika představuje problém obsesivního cvičení jako kompenzačního mechanismu u klientky $\mathrm{s}$ historií anorexie $\mathrm{v}$ anamnéze, $\mathrm{v}$ současnosti trpící záchvatovitým přejídáním. Druhá kazuistika na obsesivní cvičení nahlíží z pohledu syndromu závislosti u klientky s historií alkoholové závislosti v rodinné anamnéze a se znaky vlastní alkoholové závislosti. Odlišné prř́činy a průběh vedly k odlišným intervenčním postupům u obou př́ípadů, které jsou v textu přiblíženy. Hlavními faktory efektivní léčby byly vlastní uvědomění si potřeby pomoci ze strany klientek, posílení sociální opory a intervence založená na skutečných př́činách obsesivního cvičení ve smyslu závislosti nebo kompenzace záchvatovitého přejídání.

Klíčová slova: anorexie; cvičení; záchvatovité přejídání; závislost

\section{OBSSESSIVE EXERCISE AS AN ADDICTION OR A MECHANISM OF COMPENSATION IN EATING DISORDERS}

\section{Abstract}

The paper from psychological praxis presents two case studies of clients who have sought professional help because of their problems with obsessive exercise having a negative impact on their personal and work life and affecting both their health and mental state. In today's society that puts great pressure on performance and physical appearance, the regular exercise as part of a healthy lifestyle is a desirable strategy for increasing strength and perseverance. It can therefore be easy to appreciate even the excessive exercise and to consider it a proof of physical and mental strength. In the following case studies, it is obvious that both women did not realize the real impact of their behavior until after several years of intense day-to-day workouts lasting from three to six hours a day, when they had to organize their personal and work life around exercise units instead of working out for health or joy.

The first case study presents a problem of obsessive exercise as a compensatory mechanism in a client with a history of anorexia nervosa, currently suffering from binge-eating disorder. The second case study looks at obsessive exercise as a form of the addiction syndrome in a client with a family history of alcohol addiction and a personal history of features of alcohol addiction. Different causes and development led to different intervention procedures in both cases, which are described in the study. The main factors of an effective treatment were clients' self-awareness of the need for help, strengthening the social support system, and intervention based on the real causes of obsessive exercise in terms of either addiction or compensation of binge eating.

Keywords: anorexia; exercise; binge eating; addiction

Došlo: 6. 2. 2018

Schváleno: 7. 3. 2018 


\section{Úvod}

V tomto textu jsou představeny kazuistiky dvou klientek ${ }^{1}$, které mne během minulého roku vyhledaly se zdánlivě stejným tématem - obě trápilo excesivní cvičení, které ovládalo celý jejich osobní i pracovní život, u obou žen s sebou navíc neslo i zdravotní dopady. V obou př́padech se jednalo o mladé ženy, úspěšné pracovním životě a na okolí působící jako extrovertní, sebevědomé, velmi schopné. Obě ženy se ve svém okolí setkávaly jak s oceňováním jejich cvičebních návyků (především ze strany přátel), tak s jejich odsuzováním (ze strany rodiny). Důvody, proč se rozhodly vyhledat pomoc, příčiny jejich problému se cvičením i možnosti jeho zvládání jsou velmi rozdílné, jak vyplynulo z anamnézy a následných sezení, a jak ilustrují jejich kazuistiky popsané níže.

\section{1. kazuistika: Obsesivní cvičení jako kompenzační mechanismus u poruch příjmu potravy (klientka Alena, 34 let)}

Prvotní zakázkou bylo pomoci odpoutat se od přehnaného cvičení, které Aleně omezuje život. Alena pracuje na vysoké škole, v současné době žije sama, k vyhledání odborné pomoci se odhodlávala už asi dva roky. Impulsem k řešení svých potíží byla sklíčená nálada, kterou poslední měsíce pocit’uje téměř neustále, zvláště když přemýšlí o svém životě. Alena uvádí, že má pocit, že nežije, jenom přežívá, její dny se točí jen kolem cvičení, často kvůli tomu dochází k hádkám s rodiči nebo Alena nestíhá plnit jiné povinnosti, zanedbává přátele, práci. Při prvních konzultacích bylo možné vytvořit si následující obraz o Alenině anamnéze a současném stavu.

Alena od svých 19 do 21 let trpěla mentální anorexií, která se začala projevovat v době nástupu na vysokou školu. Nejprve si neuvědomovala, co se s ní děje, jídlo začala vynechávat, aby ušetřila nebo protože nebyl čas, ale později zjistila, že ji pocit prázdného žaludku a určitého sebe-týrání těší, naplňuje pozitivními emocemi. Začala hladovění používat jako trest např́klad za neúspěch u zkoušky (přičemž neúspěchem bylo jakékoli hodnocení nižší než A), ale také za hádky rodičů nebo rozchod sestry s přítelem. Cokoli špatného, co se v jejím okolí dělo, přisuzovala svému špatnému chování nebo slabému charakteru a odpírání jídla považovala za trest, který si zaslouží. V té době v podstatě denně hladověla, ale jinými způsoby se cíleně o hubnutí nesnažila. Alena si vzpomíná, že ji těšilo, když z jejího těla zmizely ženské křivky a hubené tělo jí připadalo velmi atraktivní. V tom ji utvrzovala i její matka, která ji vždycky chválila, jak je hezky hubená a říkala, že jí štíhlost závidí. Pro Alenu se tak vyhublá postava stala symbolem něčeho žádoucího, něčeho, v čem má nad ostatními navrch a co si musí udržet.

Anorexii překonala částečně vlastním úsilím, pomohlo jí prý hlavně to, že navázala vztah a její partner ji velmi podporoval, v jeho prrítomnosti jídlo vůbec neřešila. Po rozchodu a po krátkém období zdravého př́stupu k jídlu se u Aleny objevily problémy se záchvatovitým přejídáním. V momentě, kdy si dovolila jíst dříve zakázaná jídla (jídla s cukrem, moukou, tuky), se nedokázala ovládnout a snědla extrémní množství. Nejprve šlo o záchvaty dvakrát až třikrát do měsíce, postupně se frekvence zvyšovala až na šest záchvatů týdně. V tomto stavu Alena funguje dodnes, některé týdny je to lepší (dojde k maximálně čtyřem záchvatům), jindy se jedná o celý týden přejídání někdy i dvakrát denně. Ze strachu, aby nepřibrala, začala Alena přibližně rok po epizodě mentální anorexie cvičit, nejprve asi půl hodiny třikrát do týdne. Cvičení ji bavilo, cítila se po něm dobře, ale neměla potřebu cvičit víc.

\footnotetext{
${ }^{1}$ Jména obou klientek jsou v textu pozměněna.
} 
Občas šla s kamarádkou na veřejné hodiny fitness, jinak cvičila doma po škole nebo po práci. $\mathrm{S}$ nástupem záchvatů přejídání a s jejich narůstající frekvencí začala Alena zvyšovat i dobu strávenou cvičením. Postupně se dostala až do současné situace, tedy na tři hodiny každé ráno, někdy doplněné o další dvě hodiny odpoledne, pokud má kratší pracovní den nebo pokud sní večer předtím zvláště velké množství jídla. Cvičení pro ni nepředstavuje radost nebo koníček, ale jedná se opět o sebe-trestání, jako tomu bylo dřive u hladovění. Cvičí, i když je vyčerpaná, unavená nebo nemocná - pokud se večer přjejí, ráno následuje cvičení. Dříve cvičila i hned po epizodách přejídání, ale většinou se rychle dostavila nevolnost. Intenzivní ranní cvičení, které představuje velký výdej energie, vede ale k tomu, že Alena má ihned po ránu hlad, který ještě víc posílí odpírání jídla v první polovině dne, kterým se dále snaží kompenzovat přejídání. Oba způsoby kompenzace dostávají Alenu do začarovaného kruhu neustálého cvičení, hladovění a přejídání. Pokud se přejí, nutí se k extrémnímu cvičení a hladovění, které oboje vede k další epizodě přejídání, když se Alena dostane vyhladovělá večer domů. Zpravidla v té chvíli nedovede myslet už na nic jiného než na to, co všechno sní. Často se při přejídání přistihne, že jí v hlavě běží myšlenky ospravedlňující přejídání, protože druhý den ráno bude přeci cvičit a nají se nejdřív v poledne. Alena si uvědomuje, že takto dál nemůže fungovat, svůj život dělí mezi cvičení, práci a přejídání. Poslední dobou stále častěji uvažuje o založení rodiny, ale nedokáže si představit, že by to bylo v její situaci možné.

Dosavadní pokusy o překonání problému Alena vždy zaměřovala na cvičení jako hlavní problém - snažila se tedy přestat cvičit. Toto řešení bylo neúspěšné, protože vedlo ke zvýšené úzkosti a Alena často odešla dřív z práce, aby si vše odcvičila odpoledne místo svého ranního maratonu. Vzhledem k etiologii jejích potíží, která se od počátku týká potřeby trestat se za vše, co se nedaří, nezávisle na tom, zda tyto situace zaprríčinila ona sama, a dále potřeby být v něčem lepší než ostatní, dokázat, že je dostatečně dobrá, aby ji okolí mělo rádo, a dále vzhledem k vývoji jejích symptomů od mentální anorexie k záchvatovitému přejídání se jako stěžejní jeví práce s vlastním sebepřijetím a soustředění se na přejídání jako problém místo na cvičení jako kompenzaci. Při práci s klientkou jsme se soustředily na porozumění naznačenému začarovanému kruhu, do kterého se kompenzačními mechanismy dostává. Vstoupit do kruhu ve fázi přehnaného cvičení se ukázalo jako neefektivní, proto jsme začaly s úpravou ve fázi dopoledního odmítání jídla. Místo toho jsme se zaměřily na pravidelný jídelní režim, který jsme kontrolovaly na základě jídelních záznamů, které si Alena denně vyplňovala. V záznamech jsme se soustředily především na myšlenky spojené s jídlem, ale zaznamenávala také nutkání ke cvičení nebo k hladovění, která se přes den objevovala. Toto opatření bylo první cestou, jak řešit Alenino večerní přejídání, dále jsme se zaměřily na alternativní formy chování, které by nahradily záchvaty přejídání a které by dále pomohly zvládat nutkání k přehnanému cvičení. Bylo třeba nahradit Alenin večerní stereotypní scénár̆, kdy si nachystala veškeré jídlo, které měla v ledničce, odnesla si jej do postele a tam všechno snědla. S Alenou jsme vytvořily náhradní scénář a dále krizový plán, ke kterému se Alena mohla uchýlit v momentě, kdy potřeba přejíst se byla nejsilnější. Tyto behaviorální strategie, spojené s prací s iracionálními myšlenkami, které Alenu neustále trápily (např́íklad „Když nebudu cvičit, budu tlustá“, „Když se přejím, budu št’astná“, „Musím cvičit alespoň tři hodiny, nic jiného si nezasloužím“, „Žiju sama, protože jsem hnusná a tlustác), postupně pomohly snížit frekvenci přejídání a nutkání k extrémnímu cvičení. V současné době dále pracujeme s některými osobnostními rysy klientky, které brání úplnému zvládnutí jejích potíží, jako je nedostatek sebevědomí nebo negativní vnímání svého těla i své osobnosti. 


\section{2. kazuistika: Obsesivní cvičení jako závislost (klientka Jana, 31 let)}

Klientka Jana si dlouho nepřiznávala, že by její každodenní cvičení trvající většinou čtyři, ale někdy až sedm hodin, mohlo být problém. Má sedavé zaměstnání, a tak je pro ni cvičení prostě součást zdravého životního stylu. Poprvé začala přemýšlet o tom, že je něco špatně, před pěti lety. Tehdy trávila část letní dovolené na chalupě u rodičů a když si její matka všimla, že dcera vstává denně ve tři hodiny ráno a do sedmi hodin intenzivně cvičí, byla vyděšená. Snažila se Janě vysvětlit, že něco takového není normální, ale vedlo to pouze $\mathrm{k}$ hádce a Jana odjela od rodičů předčasně zpátky $\mathrm{k}$ sobě domů. Po této hádce si ale začala stále častěji všímat, že cvičení se pro ni stalo něčím víc než jenom koníčkem. Kromě toho, že cvičení začalo ovládat její život, objevily se zdravotní problémy a již dva roky trvající ztráta menstruace, kterou se doposud nepodařilo vyvolat.

Jana nebyla nikdy sportovní typ a cvičení pro ni bylo pouze něco, co dělala z povinnosti na hodinách tělocviku. V rodinné anamnéze Jany se objevuje alkoholová závislost ze strany otce, která rodinnou dynamiku silně ovlivňovala po celé Janino dětství i dospívání. Zatímco matka a sestra se s otcem kvůli pití hádali, Jana byla většinou na jeho straně, jak říká, byla tátova holčička a v jejích očích nemohl udělat nic špatného. Když Jana odešla na vysokou školu, začala si užívat velkoměstský život a nadměrné pití alkoholu pro ni bylo každodenní záležitostí. Během prvních tř́i let vysoké školy pila denně a několikrát do týdne do úplné opilosti. Když nastoupila do magisterského studia, začala se zajímat o zdravý životní styl a spolu s tím začala i pravidelně cvičit. V té době chodila s kamarádkami dvakrát až třikrát týdně na skupinové lekce a byla to pro ni především zábava. Postupně ale cvičení v jejím životě získalo jinou, mnohem důležitější roli. Nejprve začala cvičit každý den alespoň hodinu a cvičení se pro ni stalo nutností, přinášelo jí zábavu, ale také způsob zvládání stresu nejprve ve škole, později v práci. Bez cvičení už si svoje ráno nedovedla představit, a tak cvičila i při nemoci, při zraněních, ve svém režimu pokračovala dokonce $v$ době, kdy si zlomila tři prsty na noze. Nejhorší pro ni bylo období dovolených, kdy jezdila s kamarády nebo s rodinou pryč a najednou nemohla cvičit. Když k tomu došlo poprvé, ihned po návratu z dovolené se pustila do cvičení a cvičila šest hodin v kuse do úplného vyčerpání. Současně ji ale toto vyčerpání dodávalo jakousi euforii, kterou si chtěla udržet. Ihned další den si tedy opět zacvičila, tentokrát čtyři hodiny, a rozhodla se tento režim udržovat nadále. Posledních několik let tedy cvičí čtyři hodiny denně a aby to zvládala spolu s prací, vstává ve tři hodiny ráno. Pokud musí jet na služební cestu nebo dorazit do práce brzy ráno, vstane třeba i v jednu hodinu ráno, aby si stihla odcvičit svůj plán. Přesto často dojde $\mathrm{k}$ tomu, že po návratu domů se opět hned převlékne a cvičí jednu až tři další hodiny. Na cvičení myslí neustále, například na pracovních poradách, v kanceláŕi u počítače, cestou z práce - celý svůj život si Jana organizuje podle cvičení.

Janin způsob života výrazně poznamenává její emoční prožívání, neustále pocituje úzkost z toho, že si nebude moci zacvičit. Pokud z nějakého důvodu nemůže cvičit ráno a musí čekat do večera, celý den zaživá extrémní tenzi. Pokud ji během cvičení někdo vyruší, at' už jde o telefonní hovor nebo návštěvu, cítí intenzivní vztek, který se někdy mění až v pocit zoufalství. Jana sama rríká, že si připadá jako posedlá, jako by cvičení vymazalo veškeré další části jejího života. Tato posedlost výrazně zasahuje do Janina sociálního života. V dnešní době už se vyhýbá jakýmkoli událostem, které by mohly narušit její cvičební rozvrh - nejezdí na dovolenou, nechodí s přáteli na večeře nebo do divadla, protože se bojí, že by ráno nedovedla včas vstát. Vynechává oslavy narozenin nebo svatby kamarádek, protože by musela odjet pryč a nemohla ráno cvičit. Často se na poslední chvíli omluvila ze schůzky, 
protože cítila potřebu si namísto setkání zacvičit. Během posledních tř̌i let se okruh jejích př́tel zmenšil na úplné minimum.

Jana se svůj problém nikdy nesnažila aktivně vyřešit - pouze dvakrát zkusila ráno necvičit, ale po celodenní úzkosti oba pokusy skončily cvičením do pozdních nočních hodin. Před půlrokem začala ve spolupráci s gynekoložkou a praktickým lékařem řešit své zdravotní problémy, ale bez jakýchkoli úspěchů, protože se během vyšetření nepřiznala ke svému problematickému vztahu ke cvičení a k tomu, jak extrémní zátěž na sebe klade. Pokud se nevzdá svého způsobu cvičení, léčba nepřinese úspěchy, ale vzdát se ho nedokáže. Při sezeních objevujeme paralelu mezi současnou situací a Janiným dřívěším vztahem k alkoholu, který jí přinášel podobné pocity jako nyní cvičení. Současná Janina situace nabízí řadu podobných rysů jako syndrom závislosti na návykových látkách (viz Mezinárodní klasifikace nemocí MKN-10, 1992). I zde se objevuje bažení po své závislosti, silná, přemáhající touha opakovaně „brát látku“, tj. cvičit. Stejně tak se objevují i potíže v sebeovládání, pokud jde o dobu cvičení a její navyšování, což souvisí i s utvářením tolerance na původní „dávku“. Pocity, které Janě dříve poskytovala hodina cvičení, dnes vyvolají minimálně tři až čtyři hodiny intenzivní aktivity, často i dvakrát během dne. Pokud si Jana ráno nezacvičí, během celého dne zaživá nervozitu, nesoustředěnost, je plačtivá nebo naopak rozčilená, vzteklá. Důležitým symptomem, který je u Jany stále výraznější, je zanedbávání jakýchkoli jiných zájmů nebo sociálních kontaktů, dochází k prioritizaci cvičení před všemi ostatními oblastmi Janina života. I přes zmíněné skutečnosti, opakující se konflikty s rodinou nebo vážné zdravotní problémy ale Jana nadále setrvává u svého excesivního cvičení a nedovede přestat. V př́padě syndromu závislosti se dle MKN-10 (1992) musí alespoň tři symptomy objevovat pod dobu jednoho roku, Janina anamnéza nasvědčuje, že se s téměř všemi symptomy potýká již několik let.

Prvním krokem řešení Janiny současné situace bylo právě uvědomění si této paralely a veškerých dopadů, které cvičení na její život má. Důležité bylo odkrytí emocí, které se s cvičením spojují a uvědomění si toho, jaké potřeby si Jana cvičením naplňuje a jakým se naopak vyhýbá. Jana sama byla překvapena, nakolik z jejího života kvůli cvičení vymizel jakýkoli sociální aspekt. Protože úplné odstranění cvičení se Janě dříve neosvědčilo, a navíc ani tento postup nelze při pozitivních dopadech pohybové aktivity na zdraví člověka považovat za žádoucí, zaměřily jsme se na postupné snižovaní množství cvičebních jednotek a nahrazení vzniklého časového prostoru jinými aktivitami, které jsou pro Janu důležité a naplňující. Významnou úlohu pro Janu hrálo kromě vytvoření si repertoárů náhradních aktivit a také tréninku metod práce se stresem, úzkostmi nebo vztekem, postupné znovuobnovování vztahů s práteli a návrat ke společenským aktivitám.

\section{Závěr}

Obě popsané kazuistiky se věnovaly problémům spojeným s obsesivním cvičením. V dnešní společnosti je vlivem sociálních médií víc než kdy dřív krásné tělo něčím žádoucím, co nám dodává pocit, že jsme dosáhli něčeho důležitého. Cvičení ale nemusí být jen cestou k hezké postavě nebo součástí zdravého životního stylu či společenskou aktivitou, které se věnujeme $\mathrm{s}$ práteli. Může se naopak jednat o mechanismus, který vede k narušení psychického i fyzického zdraví, jak obě kazuistiky dokládají. Ačkoli oba případy představují obsesivní cvičení $\mathrm{z}$ jiného pohledu - v př́padě první klientky jako způsob kompenzace vysokého př́jmu energie při záchvatovitém přejídání, v prŕpadě druhé klientky jako závislost nesoucí podobné rysy jako závislosti na návykových látkách, obě kazuistiky mají také řadu rysů společných. 
U obou mladých žen došlo k rozvoji potíží při nástupu na vysokou školu, v momentě prvního osamostatnění od rodiny. U obou klientek jsou v rodinné dynamice patrné problematické rysy, at' už jde o alkoholovou závislost otce Jany nebo vyzdvihování dceřiny vyhublosti a žárlivost na ni v príípadě Aleny.

Může být velmi snadné považovat přehnané cvičení za žádoucí chování, klientky samy si svůj problém velmi dlouho neuvědomovaly a ve svém okolí se setkávaly s řadou kladných ohlasů a ocenění od svých prráteli, kteří si práli, aby je cvičení také tak bavilo. Jak ale kazuistiky ukazují, je zde výrazný rozdíl mezi cvičením pro zdraví a radost a cvičením, které nahrazuje jiné aspekty života, vyplňuje veškerý čas, ovlivňuje negativně vztahy, práci nebo i reprodukční zdraví. Kromě uvědomění si potřeby pomoci ze strany klienta $\mathrm{v}$ obou případech sehrály důležitou roli i blízké vztahy a intervence založená na př́činách obsesivního cvičení, díky které bylo možné již v prvních stádiích léčby určit, zda je obsesivní cvičení hlavním problémem (zde ve smyslu závislosti) nebo způsobem, jak kompenzovat jinou diagnózu (zde záchvatovité přejídání).

\section{Literatura}

Mezinárodní klasifikace nemocí: mezinárodní statistická klasifikace nemocí a přidružených zdravotnich problémů ve zněni desáté decenální revize MKN-10. (1992). Vyd. 3. Praha: Ústav zdravotnických informací a statistiky České republiky.

\section{Údaje o autorce:}

PhDr. Lenka Mynaříková, Ph.D. působí jako sociální a školní psycholožka a jako odborná asistentka na Českém vysokém učení technickém. Věnuje se problematice detekce lži, poruchám př́ijmu potravy, arteterapii, emoční a sociální inteligenci dětí.

\section{Kontaktní údaje:}

Adresa: Masarykův ústav vyšších studií, Kolejní 2a, Praha 6

E-mail: lenka.mynarikova@cvut.cz

Mynaříková, L. (2018). Obsesivní cvičení jako závislost nebo kompenzační mechanismus u poruch př́ijmu potravy. E-psychologie, 12(1), 53-58. http://e-psycholog.eu/pdf/mynarikova3.pdf 